\title{
sciendo
}

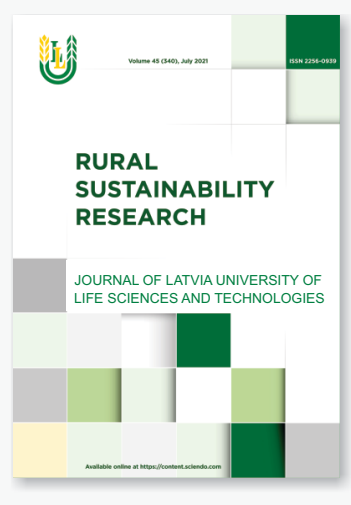

\section{Theoretical and Experimental Investigation of the Thermal Inactivation of Thermoanaerobacterium Thermosaccharolyticum and Geobacillus Stearothermophilus in Different Canned Food Matrices}

\author{
*Evalds Raits ${ }^{1,2}$, Svetlana Raita ${ }^{3,4}$, Asnate Kirse-Ozolina ${ }^{1}$, Sandra Muizniece-Brasava \\ ${ }^{1}$ Latvia University of Life Sciences and Technologies, 22Rig a street, Jelgava, Latvia \\ ${ }^{2}$ Kronis Ltd., 8 Darznieku street, Bauska, Latvia \\ ${ }^{3}$ Riga Technical University, 12-K1Azenes street, Riga, Latvia \\ ${ }^{4}$ Institute of Food Safety, Animal Health and Environment, 3 Lejupes street, Riga, Latvia
}

\begin{abstract}
In the canning industry, thermal preservation processes typically are designed based on Clostridium botulinum thermal destruction kinetics. However, some bacteria can still survive, necessitating implementation of stricter timetemperature regimen for sterilization process. The aim of this study was to compare processing effectiveness at $\mathrm{F}_{0}$ (sterilization value) $8 \pm 1 \mathrm{~min}$ from the perspective of the vegetable-based product canning facility, while analyzing the inactivation, viability, and recovery of thermophilic bacteria. Four commercial products [tomato soup and rassolnik soup - acidified food (AF), and mushroom soup and pea porridge - low-acid food (LACF)] with different heat transfer characteristics (convection and conduction) were inoculated with $6.6 \log _{10}$ spores $/ \mathrm{ml}$ Geobacillus stearothermophilus LMKK 244 (reported as DSM 6790 and ATCC 10149 in other collections) and $4.8 \log _{10}$ spores/ml Thermoanaerobacterium thermosaccharolyticum DSM 571 spore suspensions. Food samples contaminated with bacterial spores were processed in a steam-air retort at $118^{\circ} \mathrm{C}$ for 75 min. G. stearothermophilus and T. thermosaccharolyticum growth was not detected in AF samples $(\mathrm{pH}=4.4$ and 4.5$)$, but was observed in LACF samples $(\mathrm{pH}=5.1$ and 5.8). Practical evaluation showed that $T$. thermosaccharolyticum did not survive thermal processing, which was verified using a presence/absence test after incubation at $55{ }^{\circ} \mathrm{C}$. G. stearothermophilus did not survive thermal processing, but recovered in pea porridge $(\mathrm{pH}=5.8)$ during incubation. Our observations showed that food $\mathrm{pH}$ is a crucial factor determining microorganism survival during heat treatment and may be used by the vegetable-based product canning facilities to improve the food sterilization conditions.
\end{abstract}

Keywords: thermal destruction, thermophilic bacteria, retort sterilization, F0, D value.

\section{Introduction}

In the canning industry, thermal preservation processes are designed based on the $\mathrm{pH}$ of the product, which can be categorized as low-acid food (LACF) with $\mathrm{pH}>4.6$ (FDA, 2020) (or $\mathrm{pH}>4.5$ in some European countries) (Bratt, 2013) and acidified food (AF) with $\mathrm{pH}<4.6$. This threshold has been set to restrain the production of the botulin toxin by the mesophilic spore-forming bacterium, Clostridium botulinum, as both growth and toxin production are inhibited at $\mathrm{pH}<4.6$. The $12 \mathrm{D}$ process, which can destroy this bacterial population by a factor of $10^{12}\left(12 \log _{10}\right.$ cycles $)$, is used for LACF products. The minimum sterilization value (
$F_{10}^{121.1^{\circ} \mathrm{C}}$ in this case is $2.8 \mathrm{~min}$, as the $D^{121.1^{\circ} \mathrm{C}}$ value (the time required for $1 \log _{10}$ reduction of microorganism) of $C$. botulinum is $0.20 .3 \mathrm{~min}$ and the $\mathrm{z}$ value (temperature required to achieve $1 \log _{10}$ change in $\mathrm{D}$ value) is $10{ }^{\circ} \mathrm{C}$. This sterilization value threshold should be considered as the minimum threshold for LACF (Teixeira, 2006).

Nonetheless, although the product is virtually safe for consumption, some microorganisms may withstand this time-temperature regimen. From the perspective of the canning facility where this experiment was carried out, a thermal processing regimen targeting thermophilic sporeforming bacteria that can spoil the products is urgently 
Theoretical and Experimental Investigation of the

required. There are bacterial species that can grow in AF products. One of the most common organisms associated with spoilage of food is the thermophilic Bacillus coagulans (André, Vallaeys, \& Planchon, 2017), which can grow in LACF products at moderately low $\mathrm{pH}\left(\begin{array}{ll}4.2 & 4.3\end{array}\right)$ and can endure high temperatures $\left(D^{110^{\circ} \mathrm{C}}=0.27 \mathrm{~min}, \mathrm{z}=8.3^{\circ} \mathrm{C}\right)($ Peng et al., 2012); furthermore, $F^{121.1^{\circ} \mathrm{C}}=0.26 \mathrm{~min}$ is required to eliminate it by a factor of $10^{12}(12 \mathrm{D}$ concept). Numerous surveys have reported the cause of microbial spoilage of LACF canned food, which has been discussed in detail by André, Vallaeys and Planchon, 2017. The most common species that cause food spoilage are Geobacillus stearothermophilus, Thermoanaerobacterium thermosaccharolyticum, Moorella thermoacetica, Bacillus coagulans, Bacillus smithii, and Bacillus licheniformis, the D values of which are summarized in Table 1.

Table 1

\section{$D$ values (min) of selected bacteria obtained from literature}

\begin{tabular}{|c|c|c|c|c|c|c|c|c|c|}
\hline Microorganisms & $\mathrm{pH}^{12}$ & $\mathrm{D}_{105}$ & $\mathrm{D}_{110}$ & $\mathrm{D}_{115}$ & $\mathrm{D}_{116}$ & $\mathrm{D}_{120}$ & $\mathrm{D}_{121}$ & $\mathrm{D}_{125}$ & $\mathrm{z}$ \\
\hline G. stearothermophilus ${ }^{1}$ & 6.0 & & & 3.14 & & 1.25 & & 0.26 & $8-12$ \\
\hline G. stearothermophilus ${ }^{1}$ & 5.0 & & & 2.49 & & 0.59 & & 0.20 & $8-12$ \\
\hline G. stearothermophilus ${ }^{1}$ & 4.0 & & & 1.39 & & 0.43 & & 0.10 & $8-12$ \\
\hline G. stearothermophilus $s^{2,3,4}$ & & & & & & & $\begin{array}{l}4.00- \\
5.00\end{array}$ & & \\
\hline G. stearothermophilus ${ }^{5}$ & & & & & & & 2.53 & 0.64 & 7.42 \\
\hline G. stearothermophilus ${ }^{6}$ & 7.0 & & & 10.00 & & & & & \\
\hline T. thermosaccharolyticum ${ }^{7}$ & 6.6 & & 12.16 & & & & & & \\
\hline T. thermosaccharolyticum ${ }^{8}$ & 6.6 & 11.80 & & & & & & & \\
\hline T. thermosaccharolyticum ${ }^{2,3,4}$ & & & & & & & $\begin{array}{l}3.00- \\
4.00\end{array}$ & & \\
\hline T. thermosaccharolyticum ${ }^{6}$ & 7.0 & & & & 10.00 & & & & \\
\hline Moorella thermoacetica ${ }^{6}$ & 7.0 & & & & & & $\begin{array}{l}83.00- \\
111.00\end{array}$ & & \\
\hline Moorella thermoacetica ${ }^{9}$ & 7.0 & & & & & & & 10.00 & $\begin{array}{l}6.10- \\
8.60\end{array}$ \\
\hline Bacillus coagulans ${ }^{10}$ & & 1.32 & 0.16 & & & & & & 8.68 \\
\hline Bacillus licheniformis ${ }^{11}$ & & & & & & 0.18 & & & \\
\hline Bacillus smithii ${ }^{6}$ & 7.0 & 10.00 & 10.00 & & & & & & $\begin{array}{l}6.10- \\
7.80\end{array}$ \\
\hline
\end{tabular}

${ }^{1}$ López et al., 1997; ${ }^{2}$ Jay, Loessner, \& Golden, 2005; ${ }^{3}$ Ababouch, 2014; ${ }^{4}$ Warne, 1988; ${ }^{5}$ Somavat et al., 2012; ${ }^{6}$ André, Zuber, \& Remize, 2013; ${ }^{7}$ Mtimet et al., 2016; ${ }^{8}$ Ahn, Balasubramaniam, \& Yousef, 2007; ${ }^{9}$ Byrer, Rainey, \&Wiegel, 2000; ${ }^{10}$ Peng et al., 2012; ${ }^{11}$ Janštová \& Lukášová, 2001; ${ }^{12}$ Given $\mathrm{pH}$ values indicates medium $\mathrm{pH}$ at which D value was measured.

Previously, several of these bacteria were detected in experimental Kronis Ltd. (Latvia, Bauska) canned ready-toeat meals. Spoiled products were analyzed at the Latvian National Reference Laboratory (BIOR), and the isolated microorganisms were identified using matrix-assisted laser desorption ionization time-of-flight mass spectrometry. The most common thermophilic bacterial isolates were $B$. smithii, $B$. licheniformis, G. stearothermophilus, and $T$. thermosaccharolyticum. Better understanding of heat penetration into the product core during sterilization and consequent modifications in the time-temperature process has circumvented the problems associated with food spoilage by the $B$. smithii and $B$. licheniformis. However, the latter two are significantly more heat-resistant; for example, to achieve $12 \log _{10}$ reduction of $G$. stearothermophilus $\left(\mathrm{D}_{121}=5 \mathrm{~min}\right)$, it is necessary to achieve $F^{101.1 \mathrm{C}}=60 \mathrm{~min}$, which is not possible because of considerable reduction in product quality parameters (Kirse-Ozolina et al., 2019). 
G. stearothermophilus and T. thermosaccharolyticum are thermophilic spore-forming bacteria that grow between 45 ${ }^{\circ} \mathrm{C}$ and $70{ }^{\circ} \mathrm{C}$, with an optimum temperature between $50{ }^{\circ} \mathrm{C}$ and $60{ }^{\circ} \mathrm{C}$ (Jay; Loessner, \& Golden, 2005). The optimal pH and minimal $\mathrm{pH}$ for growth of G. stearothermophilus are 7.7 (Mtimet et al., 2015) and 4.8-5.0, respectively (Durand et al., 2015), whereas they are 6.5 and 4.1 (Mtimet et al., 2016), respectively, for $T$. thermosaccharolyticum. G. stearothermophilus causes "flat sour" (Durand et al., 2015) spoilage of canned food, and T. thermosaccharolyticum has been called "the swelling canned food spoiler" (da Silva et al., 2018) because of gas production during growth (DelvesBroughton, 2008).

As the D values for G. stearothermophilus and $T$. thermosaccharolyticum vary in literature (Table 1), in this study, we decided to compare processing effectiveness at $\mathrm{F}_{0}=$ $8 \pm 1$ min from the perspective of the canning industry, while analyzing the inactivation, viability, and recovery of selected thermophilic bacteria and heat transfer in AF/LACF products. This study will enhance our understanding regarding the thermal sterilization process targeting thermophilic bacteria, which will be useful for generating safer canned food products.

\section{Materials and Methods}

\section{Tested products}

Four commercial products with different $\mathrm{pH}$ and heat transfer types were selected for this study (Table 2).

\section{Canned food products}

\begin{tabular}{|c|c|c|c|c|c|}
\hline Product & $\begin{array}{l}\text { Heat transfer } \\
\text { type }\end{array}$ & Structure description & Group & $\mathrm{pH}$ & $\begin{array}{l}\text { Water } \\
\text { activity }\left(a_{\mathrm{w}}\right)\end{array}$ \\
\hline $\begin{array}{l}\text { Tomato } \\
\text { soup }\end{array}$ & Convection & Thick liquid, ready-to-eat tomato soup puree & $\mathrm{AF}$ & 4.4 & 0.99 \\
\hline $\begin{array}{l}\text { Mushroom } \\
\text { soup }\end{array}$ & Convection & $\begin{array}{l}\text { Liquid soup concentrate, which consists of } \\
\text { shredded mushroom pieces in a broth }\end{array}$ & LACF & 5.1 & 0.98 \\
\hline Pea porridge & Conduction & $\begin{array}{l}\text { Solid pea porridge without liquid phase, but } \\
\text { of soft consistency }\end{array}$ & $\mathrm{LACF}$ & 5.8 & 0.98 \\
\hline $\begin{array}{l}\text { Rassolnik } \\
\text { soup }\end{array}$ & Conduction & $\begin{array}{l}\text { Thick soup concentrate, which consists of } \\
\text { submerged and shredded food pieces in a } \\
\text { thick liquid }\end{array}$ & $\mathrm{AF}$ & 4.5 & 0.98 \\
\hline
\end{tabular}

Tomato soup and rassolnik soup concentrate are both AFs, but with different heat transfer behaviors. The same is true for the LACF, mushroom soup and pea porridge (Kronis Ltd., Bauska, Latvia). Products were packaged in $500 \mathrm{~mL}$ glass jars, 12 units each, and pre-treated at $116^{\circ} \mathrm{C}$ for $60 \mathrm{~min}$ (holding phase) to achieve "commercial sterilization".

\section{Bacterial strain}

G. stearothermophilus LMKK 244 active culture was obtained from the Microbial Strain Collection of Latvia (University of Latvia, Riga). This strain has been reported in other collections under the numbers DSM 6790 and ATCC 10149. Freeze-dried T. thermosaccharolyticum DSM 571 was obtained from the German Collection of Microorganisms and Cell Cultures (Leibniz Institute DSMZ, Braunschweig). This strain has been reported in other collections under the accession number ATCC 7956.

\section{Media}

G. stearothermophilus LMKK 244 was grown in tryptic soy broth (TSB) ( $\mathrm{pH} 7.4$, Biolife, Milan, Italy) and tryptic soy agar (TSA) ( $\mathrm{pH} 7.4$, Biolife, Milan, Italy). Spore concentration and viable cell counts were determined by performing serial dilutions on TSA using tryptone salt broth (pH 7.0 Biolife, Milan, Italy).

T. thermosaccharolyticum DSM 571 was grown in chopped liver broth $[500 \mathrm{~g} / \mathrm{L}$ fresh beef liver (from local market), $10 \mathrm{~g} / \mathrm{L}$ peptone (Biolife, Milan, Italy), $1 \mathrm{~g} / \mathrm{L} \mathrm{K}_{2} \mathrm{HPO}_{4}$, and $1 \mathrm{~g} / \mathrm{L}$ soluble starch; $\mathrm{pH}$ adjusted to 7.0 before sterilization via autoclaving] and sporulation medium, which was chopped liver broth supplemented with $10 \mathrm{mg} / \mathrm{L}$ of $\mathrm{MnSO}_{4}$ and $10 \mathrm{mg} / \mathrm{L} \mathrm{CaCl}, \mathrm{pH}$ 6.6. All chemicals were purchased from Chempur (Karlsruhe, Germany). Spore concentration and viable cell counts were determined by performing serial dilutions on reinforced Clostridial agar (RCA, pH 6.8, Sigma-Aldrich, MO, USA) using tryptone salt broth.

\section{Spore preparation}

G. stearothermophilus was firstly pre-cultured in a 100 $\mathrm{mL}$ glass bottle containing $50 \mathrm{mLTSB}$ and incubated for $48 \mathrm{~h}$ at $55^{\circ} \mathrm{C}$ under aerobic conditions. Then, $200 \mu \mathrm{L}$ of the $48-\mathrm{h}$ culture was spread onto 135 identical TSA plates and incubated at $55{ }^{\circ} \mathrm{C}$ for 8 days, under aerobic conditions. During the incubation, the plates were placed inside plastic bags containing wet tissue to minimize dehydration of the agar. The presence of spores was visually assessed using a light microscope $(100 \times 4$ Oil ph3, Nikon, Shanghai, China) after staining with Malachite Green (Sigma-Aldrich, MO, USA). After incubation, G. stearothermophilus spores were harvested from the plates by adding $4 \mathrm{~mL}$ of sterile distilled water to the surface of each plate and scraping of the bacterial lawn with a sterile plastic spreader. The spore suspension was transferred to $50 \mathrm{~mL}$ centrifuge tubes. The samples were then washed four times with distilled water, separated via 
centrifugation $(4,700 \times \mathrm{g}, 20 \mathrm{~min})$, and stored in distilled water at $4{ }^{\circ} \mathrm{C}$ until experimental use. Prior to inoculation of the food samples, spores of G. stearothermophilus were resuspended in distilled water and heat-treated at $90{ }^{\circ} \mathrm{C}$ for $30 \mathrm{~min}$ in a water bath to eliminate vegetative cells.

The first anaerobic pre-culture of $T$.

thermosaccharolyticum DSM 571, obtained from $1 \mathrm{~mL}$ frozen aliquots, was performed in $100 \mathrm{~mL}$ liver broth in a glass jar at $55^{\circ} \mathrm{C}$ for $24 \mathrm{~h}$ with horizontal shaking (100 rpm). Ten milliliter inoculate in eight $200 \mathrm{~mL}$ glass jars containing $100 \mathrm{~mL}$ liver broth supplemented with $10 \mathrm{mg} / \mathrm{L} \mathrm{MnSO}_{4}$ and $10 \mathrm{mg} / \mathrm{L} \mathrm{CaCl}_{2}$ was used for sporulation. Sporulation was then conducted at $55^{\circ} \mathrm{C}$ for at least a month under anaerobic conditions. The presence of spores was visually assessed using a light microscope (Nikon, $100 \times 4$ Oil condenser annulus ph3) after staining with Malachite Green. The spore suspension was transferred to $50 \mathrm{~mL}$ centrifuge tubes and harvested via centrifugation $(8,000 \times g, 20 \mathrm{~min})$, washed four times with distilled water, and stored at $4{ }^{\circ} \mathrm{C}$ until experimental use. Anaerobic conditions were created in plastic 7 L containers (GENbox, bioMerieux, Lyon, France) with anaerobe paper sachets (BD GasPak ${ }^{\mathrm{TM}} \mathrm{EZ}, \mathrm{NJ}, \mathrm{USA}$ ).

\section{Inoculation offood samples}

The spore concentrates of both bacteria were resuspended in $40 \mathrm{~mL}$ aliquots, resulting in $6.6 \log _{10}$ spores of $G$. stearothermophilus and $4.8 \log _{10}$ spores of $T$. thermosaccharolyticum per milliliter. Furthermore, $36 \mathrm{~mL}$ suspension (12 mL x 3) was inoculated in four types of commercial products as follows: (1) $12 \mathrm{~mL}$ spore suspension for determining the number of spores in $1 \mathrm{~g}$ product; (2) 12 $\mathrm{mL}$ for determining the number of spores $24 \mathrm{~h}$ after sterilization; (3) $12 \mathrm{~mL}$ for determining the number and presence of spores 2 weeks after sterilization with incubation at $55{ }^{\circ} \mathrm{C}$. The remaining $4 \mathrm{~mL}$ spore suspension was used to quantify spores in $1 \mathrm{~mL}$ heat-shocked cultures and to inoculate triplicates of the target products with the aim of (4) determining the growth rate of spores in the products under optimal conditions (see below) when $12 \mathrm{~mL}$ decimal dilution of the spore suspension was used.

To determine the growth rate of $G$. stearothermophilus, 1 $\mathrm{mL}$ spore suspension was added to $500 \mathrm{~g}$ of each product in glass jars and incubated for $48 \mathrm{~h}$ at $55{ }^{\circ} \mathrm{C}$ under aerobic conditions. To determine the growth rate of $T$.

thermosaccharolyticum, $1 \mathrm{~mL}$ spore suspension was added to $100 \mathrm{~g}$ of each product in open sterile bags instead of glass jars due to technical limitations. Samples were placed in plastic $7 \mathrm{~L}$ containers with anaerobe paper sachets to create anaerobic conditions during the $72 \mathrm{~h}$ incubation at $55^{\circ} \mathrm{C}$.

\section{Cell count and presence/absence detection}

After sterilization, the contaminated and heat-treated tomato soup, rassolnik soup, mushroom soup, and pea porridge jars in triplicate were incubated at $21 \pm 2{ }^{\circ} \mathrm{C}$ for $24 \mathrm{~h}$ before cell count analysis, and in thermostats at $55^{\circ} \mathrm{C}$ for two weeks to allow germination of the bacteria that were able to survive processing temperatures. Prior to cell counting and presence/absence detection, all samples were homogenized using a dispersing system T18 Ultra-Turrax with S18N-19G headpiece (IKA, Staufen, Germany). For cell count analysis, $10 \mathrm{~g}$ of each sample was diluted with $90 \mathrm{~mL}$ tryptone salt broth. Subsequently, the serial dilutions were transferred to the plates. For presence/absence analysis, $1 \mathrm{~g}$ of the product was transferred to $10 \mathrm{~mL}$ broth. Bacterial count analysis is performed after serial dilutions and represents the microorganism count in $1 \mathrm{~g}$ product; hence, inoculation of $500 \mathrm{~g}$ sample with $1 \mathrm{~mL}$ spore suspension $(6.6 \log 10$ and 4.8 $\log 10$ respectively) indicates the limit of detection of spore count, as $2 \log _{10}$ spores are lost during the number conversions (from spores per $500 \mathrm{~g}$ of sample to spores per $1 \mathrm{~g}$ of sample). Analysed bacteria were detected during presence/absence analysis.

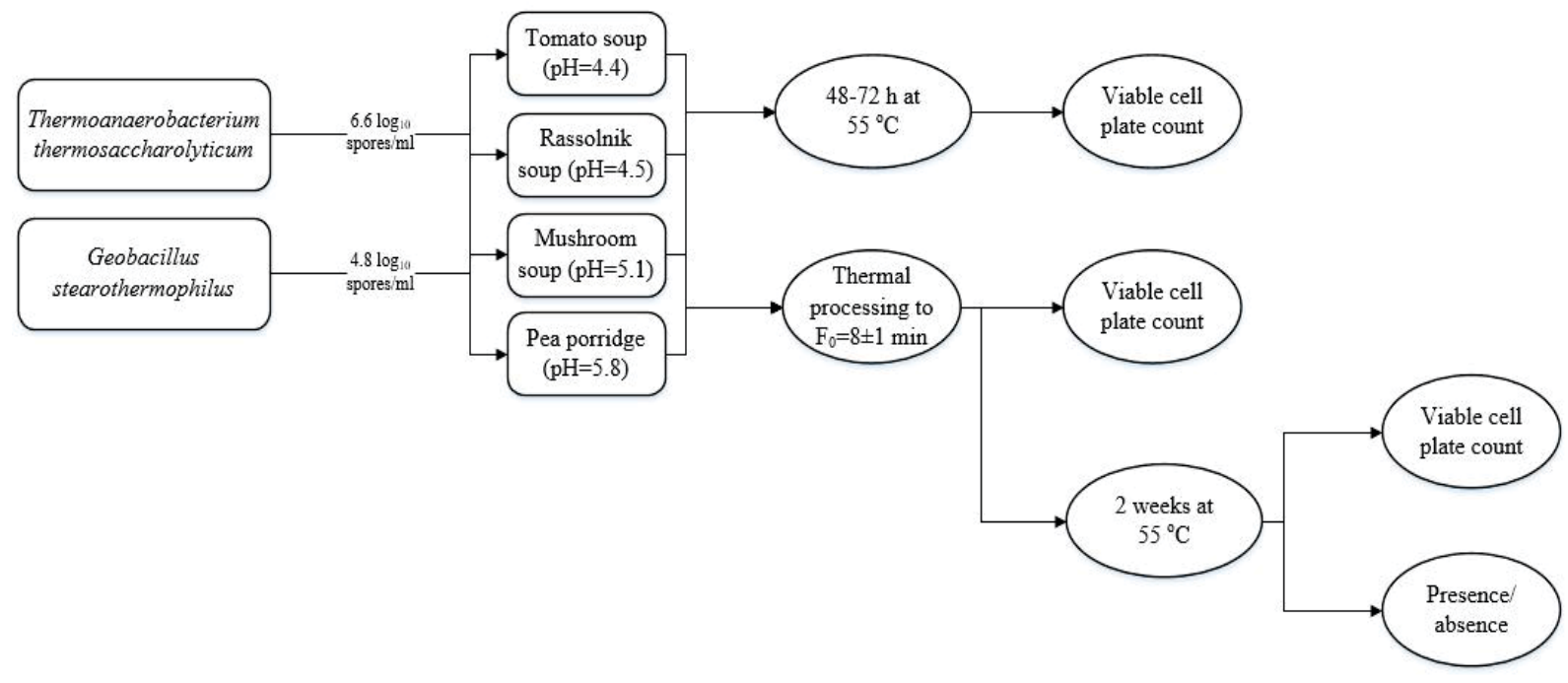

Figure 1. Study design. 


\section{Sterilization}

Sterilization of inoculated samples was performed in a SN4280 steam-air retort (Panini Ltd., Modena, Italy) at the Kronis Ltd. (Bauska, Latvia) production facilities. The process holding time was set to $75 \mathrm{~min}$ at $118^{\circ} \mathrm{C}$. The product core temperatures were measured using wireless thermocouple (Tecnosoft, Peschiera Borromeo, Italy). The sterilization value $\left(\mathrm{F}_{0}\right)$ was calculated by the general method based on the time-temperature data (Bigelow et al., 1920).

\section{Theoretical evaluation of spore count after heat treatment}

Theoretical evaluation of spore count in the product after heat treatment was performed as follows:

$$
A=B-\left(\frac{F_{0}}{D}\right)
$$

where:

A - theoretical evaluation of spores in the sample after heat treatment, $\log _{10}$;

$\mathrm{B}$ - spore concentration in inoculant, $\log _{10}$;

$\mathrm{F}_{0}$ - sterilization value calculated based on timetemperature data obtained from the core of the sample during the heat treatment, min;

D-D value of chosen bacteria, $\min$.
For theoretical evaluation, it was decided to select the highest D values found in literature, i.e. $\mathrm{D}=5 \mathrm{~min}$ for $G$. stearothermophilus and $\mathrm{D}=4 \min$ for $T$.

thermosaccharolyticum.

\section{Dataprocessing}

Theoretical evaluation of spore count was carried out in Mircosoft Excel v16.0. Represented data of microbiological analysis results are the means of three replicates. Means with p-values less than 0.05 were considered statistically significant. Descriptive statistics were carried out in IBM SPSS Statistics v26.

\section{Results}

Bacterial growth behavior in different food matrices

Bacterial growth at optimal temperature was analyzed to study bacterial behavior in the non-heat-treated samples. The results (Table 3 ) showed that the G. stearothermophilus count did not change significantly $(\mathrm{p}<0.05)$ after incubation for AF products, but increased in LACF products. $T$. thermosaccharolyticum was not detected in AF products, but were detected in LACF products $(\mathrm{p}<0.05)$. Among the tested products, pea porridge appeared to be the best medium for the growth of thermophilic bacteria.

\section{Bacterial growth in selected food matrices}

\begin{tabular}{|c|c|c|c|c|c|}
\hline \multirow{3}{*}{ Product } & \multirow{3}{*}{$\mathrm{pH}$} & \multicolumn{2}{|c|}{ Geobacillus stearothermophilus } & \multicolumn{2}{|l|}{$\begin{array}{l}\text { Thermoanaerobacterium } \\
\text { thermosaccharolyticum }\end{array}$} \\
\hline & & $\begin{array}{l}\text { Spore count in } \\
\text { the product }\end{array}$ & $\begin{array}{l}\text { Cell count after } \\
48 \mathrm{~h} \text { at } 55^{\circ} \mathrm{C}\end{array}$ & $\begin{array}{l}\text { Spore count in the } \\
\text { product }\end{array}$ & $\begin{array}{l}\text { Cell count after } \\
72 \mathrm{~h} \text { at } 55^{\circ} \mathrm{C}\end{array}$ \\
\hline & & $\log _{10} \mathrm{CFU} / \mathrm{g}$ & $\log _{10} \mathrm{CFU} / \mathrm{g}$ & $\log _{10} \mathrm{CFU} / \mathrm{g}$ & $\log _{10} \mathrm{CFU} / \mathrm{g}$ \\
\hline $\operatorname{Ts}^{1}$ & 4.4 & $2.9 \pm 0.01$ & $2.5 \pm 0.01$ & $1.1 \pm 0.01$ & $<1$ \\
\hline $\mathrm{Ms}^{2}$ & 5.1 & $2.9 \pm 0.07$ & $5.8 \pm 0.02$ & $1.1 \pm 0.07$ & 4.5 \\
\hline $\mathrm{Pp}^{3}$ & 5.8 & $2.9 \pm 0.17$ & $7.1 \pm 0.04$ & $1.1 \pm 0.18$ & 7.2 \\
\hline $\mathrm{Rs}^{4}$ & 4.5 & $2.9 \pm 0.09$ & $2.7 \pm 0.02$ & $1.1 \pm 0.08$ & $<1$ \\
\hline
\end{tabular}

${ }^{1}$ Tomato soup; ${ }^{2}$ Mushroom soup; ${ }^{3}$ Pea porridge; 4 Rassolnik soup.

Theoretical evaluation of spore count in the product

The products showed various $\mathrm{F}_{0}$ values, which were achieved during the sterilization process (Table 4). Owing to the differences in the structures of the product, which affected the heat penetration characteristics, the most liquid and homogenous product had the largest $\mathrm{F}_{0}$ values, whereas the thickest and heterogeneous product (rassolnik soup) had the lowest $\mathrm{F}_{0}$ value. This sterilization value is expected to destroy 1.4-1.6 CFU $\log _{10} / \mathrm{g}$ of $G$. stearothermophilus with $\mathrm{D}_{121}=5$ min (Table 1); therefore, the number of surviving $G$. stearothermophilus should be 2.3-2.5 CFU $\log _{10} / \mathrm{g}$ (Table 4). For $T$. saccharolyticum with $\mathrm{D}_{121}=4 \mathrm{~min}$ (Table 1$)$, the expected destruction rate is $1.8-2 \mathrm{CFU} \log _{10} / \mathrm{g}$; therefore, $0.1-0.3 \mathrm{CFU} \log _{10} / \mathrm{gcan}$ be detected via counting. 
Theoretical evaluation of spore count in the product

Table 4

\begin{tabular}{|c|c|c|c|c|c|c|}
\hline \multirow{3}{*}{ Product } & cillus & earothermophilus & & \multicolumn{3}{|c|}{$\begin{array}{l}\text { Thermoanaerobacterium } \\
\text { thermosaccharolyticum }\end{array}$} \\
\hline & $\mathrm{F}_{0}$ & $\begin{array}{l}\text { Spore } \quad \log _{10} \\
\text { reduction based } \\
\text { on reference } D_{121} \\
=5 \mathrm{~min}\end{array}$ & $\begin{array}{l}\text { Theoretical } \\
\text { cell count in } \\
\text { the product* }\end{array}$ & $\mathrm{F}_{0}$ & $\begin{array}{l}\text { Spore } \quad \log _{10} \\
\text { reduction based } \\
\text { on reference } D_{121} \\
=4 \mathrm{~min}\end{array}$ & $\begin{array}{l}\text { Theoretical } \\
\text { cell count in } \\
\text { the product* }\end{array}$ \\
\hline & $\min$ & $\log _{10} \mathrm{CFU} / \mathrm{g}$ & $\log _{10} \mathrm{CFU} / \mathrm{g}$ & $\min$ & $\log _{10} \mathrm{CFU} / \mathrm{g}$ & $\log _{10} \mathrm{CFU} / \mathrm{g}$ \\
\hline $\mathrm{Ts}^{1}$ & 8.2 & 1.6 & 2.3 & 8.0 & 2.0 & 0.1 \\
\hline $\mathrm{Ms}^{2}$ & 7.6 & 1.5 & 2.5 & 7.8 & 1.9 & 0.1 \\
\hline $\mathrm{Pp}^{3}$ & 7.3 & 1.5 & 2.4 & 7.3 & 1.8 & 0.2 \\
\hline $\mathrm{Rs}^{4}$ & 7.1 & 1.4 & 2.5 & 7.2 & 1.8 & 0.3 \\
\hline
\end{tabular}

${ }^{1}$ Tomato soup; ${ }^{2}$ Mushroom soup; ${ }^{3}$ Pea porridge; 4 Rassolnik soup;

* Theoretical spore count is based on spore count in the product (Table 5).

Growth and post-heat treatment recovery

Spore count analysis after sterilization (Table 5) did not reveal G. stearothermophilus and T. thermosaccharolyticum growth, which does not agree with the theoretical calculations (see 3.2 section).

Growth and recovery of Geobacillus stearothermophilus and Thermoanaerobacterium saccharolyticum in the product after heat treatment

\begin{tabular}{|c|c|c|c|c|c|c|c|c|c|c|}
\hline \multirow{3}{*}{$\begin{array}{l}\text { Pro- } \\
\text { duct }\end{array}$} & \multicolumn{5}{|c|}{ Geobacillus stearothermophilus } & \multicolumn{5}{|c|}{ Thermoanaerobacterium thermosaccharolyticum } \\
\hline & $\begin{array}{l}\text { Spore } \\
\text { count in } \\
\text { the } \\
\text { inoculant }\end{array}$ & $\begin{array}{l}\text { Spore } \\
\text { count in } \\
\text { the } \\
\text { product }\end{array}$ & $\begin{array}{l}\text { Cell } \\
\text { count } \\
\text { after } 22 \\
\pm 2 \mathrm{~h}\end{array}$ & $\begin{array}{l}\text { Cell } \\
\text { count* }\end{array}$ & $\begin{array}{l}\text { Cell } \\
\text { pre- } \\
\text { sence* }\end{array}$ & $\begin{array}{l}\text { Spore } \\
\text { count in } \\
\text { the } \\
\text { inoculant }\end{array}$ & $\begin{array}{l}\text { Spore } \\
\text { count in } \\
\text { the } \\
\text { product }\end{array}$ & $\begin{array}{l}\text { Cell } \\
\text { count } \\
\text { after } 22 \\
\pm 2 \mathrm{~h}\end{array}$ & $\begin{array}{l}\text { Cell } \\
\text { count* }\end{array}$ & $\begin{array}{l}\text { Cell } \\
\text { pre- } \\
\text { sence* }\end{array}$ \\
\hline & $\begin{array}{l}\log _{10} \\
\mathrm{CFU} / \mathrm{g}\end{array}$ & $\begin{array}{l}\log _{10} \\
\mathrm{CFU} / \mathrm{g}\end{array}$ & $\begin{array}{l}\log _{10} \\
\mathrm{CFU} / \mathrm{g}\end{array}$ & $\begin{array}{l}\log _{10} \\
\mathrm{CFU} / \mathrm{g}\end{array}$ & $\mathrm{g}^{-1}$ & $\begin{array}{l}\log _{10} \\
\mathrm{CFU} / \mathrm{g}\end{array}$ & $\begin{array}{l}\log _{10} \\
\mathrm{CFU} / \mathrm{g}\end{array}$ & $\begin{array}{l}\log _{10} \\
\mathrm{CFU} / \mathrm{g}\end{array}$ & $\begin{array}{l}\log _{10} \\
\mathrm{CFU} / \mathrm{g}\end{array}$ & $\mathrm{g}^{-1}$ \\
\hline $\mathrm{Ts}^{1}$ & 6.6 & $\begin{array}{l}3.9 \\
\pm 0.01\end{array}$ & $<1$ & $<1$ & - & 4.8 & $\begin{array}{l}2.1 \\
\pm 0.01\end{array}$ & $<1$ & $<1$ & - \\
\hline $\mathrm{Ms}^{2}$ & 6.6 & $\begin{array}{l}3.9 \\
\pm 0.07\end{array}$ & $<1$ & $<1$ & - & 4.8 & $\begin{array}{l}2.1 \\
\pm 0.07\end{array}$ & $<1$ & $<1$ & - \\
\hline $\mathrm{Pp}^{3}$ & 6.6 & $\begin{array}{l}3.9 \\
\pm 0.17\end{array}$ & $<1$ & $\begin{array}{l}4.7 \\
\pm 0.32\end{array}$ & + & 4.8 & $\begin{array}{l}2.1 \\
\pm 0.18\end{array}$ & $<1$ & $<1$ & - \\
\hline $\mathrm{Rs}^{4}$ & 6.6 & $\begin{array}{l}3.9 \\
\pm 0.09\end{array}$ & $<1$ & $<1$ & - & 4.8 & $\begin{array}{l}2.1 \\
\pm 0.08\end{array}$ & $<1$ & $<1$ & - \\
\hline
\end{tabular}

\footnotetext{
${ }^{1}$ Tomato soup; ${ }^{2}$ Mushroom soup; ${ }^{3}$ Pea porridge; 4 Rassolnik soup; *after 2 weeks at $55{ }^{\circ} \mathrm{C}$
}

Considering that the count analysis does not reveal the 2 CFU $\log _{10}$ that are "lost" because of number conversions from $1 \mathrm{~mL}$ of inoculant to $1 \mathrm{~g}$ of product (considering inoculation of $500 \mathrm{~g}$ of product), samples were stored at $55^{\circ} \mathrm{C}$ to create the most favorable environment for bacterial growth, followed by spore counting and presence/absence analyses. $G$. stearothermophilus was detected only in pea porridge $(\mathrm{pH}=$ 5.8), while T. thermosaccharolyticum was not detected in any sample. 


\section{Discussion}

Growth of either G. stearothermophilus and $T$. thermosaccharolyticum was not detected in AF samples $(\mathrm{pH}$ $=4.4$ and 4.5$)$, but was observed in LACF samples $(\mathrm{pH}=5.1$ and 5.8). Theoretical calculations showed that the expected detectable number of $G$. stearothermophilus and $T$. thermosaccharolyticum after sterilization were $2.3-2.5 \mathrm{CFU}$ $\log _{10} / \mathrm{g}$ and $0.1-0.3 \mathrm{CFU} \log _{10} / \mathrm{g}$, respectively. Practical evaluation showed (Table 5) that T. thermosaccharolyticum does not survive thermal processing, which was verified using a presence/absence test after incubation (2 weeks). $G$. stearothermophilus did not grow after processing, but recovered in pea porridge $(\mathrm{pH}=5.8)$ during incubation (2 weeks).

Considering that the difference in $\mathrm{F}_{0}$ values between the pea porridge and mushroom soup was not outstanding, and that both bacteria can grow in LACF products (Table 3), we expected them to grow in mushroom soup and pea porridge after 2 weeks at $55^{\circ} \mathrm{C}$. Surprisingly, spore count analysis of samples incubated in a thermostat for 2 weeks showed that $G$. stearothermophilus grew only in the pea porridge, whereas $T$. thermosaccharolyticum growth was not detected after product processing. Subsequent presence/absence analysis did not show growth of either bacterium in the products, except for that of G. stearothermophilus in the pea porridge.

This contradiction in theoretical and the empirical data (Table 4) can be explained in two ways:

a) The $D$ values of the strains used in this study were lower than those described earlier (Table 1). For example, based on the calculation, $\mathrm{F}_{0}=7.64$ is expected to destroy $6.6 \log _{10}$ spores inoculated species with heat resistance parameter $D_{121}$ $=1.2 \mathrm{~min}$. The $\mathrm{D}$ values used for the calculations are approximate for the genus in general, whereas in reality, the values may be dispersed. Kotzekidou (2014) reported variability in $\mathrm{D}_{120}$ values between various strains of $G$. stearothermophilus (1.0-5.8 min). Rigaux, Denis, Albert, \& Carlin (2013) performed a meta-analysis on $G$. stearothermophilus spore heat resistance by analyzing D values in published studies and arrived at a mean $\mathrm{D}$ value of $3.3 \mathrm{~min}$.

Various investigators have observed correlations between spore heat resistance and medium $\mathrm{pH}$, as well as sporulation conditions (temperature, $\mathrm{pH}$ ). Palop et al. (1999) found that the $\mathrm{D}_{111}$ values of $B$. coagulans spores varied from $0.49 \mathrm{~min}$ at pH 4 to 1.7 min at pH 7. Cameron, Leonard and Barrett (1980) showed that the $\mathrm{D}_{112.8}$ value of $C$. sporogenes at pH 5 is $7 \mathrm{~min}$; however, it gradually increases with $\mathrm{pH}$, and $\mathrm{D}_{112.8}=15 \mathrm{~min}$ at pH 6.5.

Mtimet et al. $(2016,2015)$ studied G. stearothermophilus ATCC 12980 and T. saccharolyticum DSM 571 spore heat resistance as a function of sporulation parameters and observed that spore heat resistance is generally higher in spores that are produced under conditions most favorable for the growth of a particular strain. In this study, spores of the $G$. stearothermophilus LMKK 244 strain, were produced under optimal conditions $\left(55^{\circ} \mathrm{C}, \mathrm{pH} 7.4\right)$. The $T$.

thermosaccharolyticum DSM 571 spores used in this study were produced under the same conditions that were considered to be most favorable for developing maximum heat resistance of spores by Mtimet et al. (2016). The D values for the strains used in this study are not available; however, we assumed that the $\mathrm{pH}$ of the product medium affected spore heat resistance, which led to higher spore destruction rate than expected.

b) Bacteria damaged during processing were not able to recover. André et al. (2021) and Mtimet et al. (2016) showed that the rate of post-heat-treatment reduction in bacterial count depends on the $\mathrm{pH}$-temperature combination; for example, for G. stearothermophilus strain 2804 138, time of first decimal reduction $(\delta)$ was $97 \mathrm{~h}$ at $\mathrm{pH} 5.0,77 \mathrm{~h}$ at $\mathrm{pH} 4.6$, and $65 \mathrm{~h}$ at $\mathrm{pH}$ 4.2. This allows us to assume that if $<2 \log _{10} \mathrm{CFU} / \mathrm{g}$ bacteria have survived, which cannot be detected using plate count analysis, G. stearothermophilus spores cannot recover in mushroom soup, and T. thermosaccharolyticum cannot recover in either mushroom soup or pea porridge after storage at $55^{\circ} \mathrm{C}$ for 2 weeks.

This study has certain limitations. Serial dilutions have to be performed to determine the bacterial count in $1 \mathrm{~g}$ of the product; as the inoculation was performed in $500 \mathrm{~g}$ of the product, we could not detect $2 \log _{10} \mathrm{CFU} / \mathrm{g}$ via counting after sterilization. However, consequent incubation ( 2 weeks at 55 ${ }^{\circ} \mathrm{C}$ ) allowed survived microorganisms to germinate and subsequent analysis of samples allowed us to obtain and extrapolate the results.

\section{Conclusions}

While designing the sterilization process based on the heat destruction characteristics of the target microorganism, the retention of the $\mathrm{D}$ value with respect to the $\mathrm{pH}$ of the product should be considered. The closer the product $\mathrm{pH}$ (4.4, $4.5,5.1,5.8)$ is to the optimum $\mathrm{pH}$ required for the growth of the target organism, which is $\mathrm{pH} 7.7$ for $G$. stearothermophilus and $\mathrm{pH} 6.5$ for $T$.

thermoanaerobacterium, the larger should be the $\mathrm{F}_{0}$ setpoint. To destroy $6.6 \log _{10}$ spores of G. stearothermophilus, $\mathrm{F}_{0}$ value of $8 \pm 1 \mathrm{~min}$ is sufficiently high for products of $\mathrm{pH} 4.4,4.5$ and 5.1 , but should be increased for products with $\mathrm{pH} 5.8$ if the product is to be subjected to tropical conditions. To destroy $4.8 \log _{10}$ spores $/ \mathrm{ml}$ of $T$. thermoanaerobaceterium, $\mathrm{F}_{0}$ value value of $8 \pm 1 \mathrm{~min}$ is sufficiently high for all studied products $(\mathrm{pH} \mathrm{4.4,} \mathrm{4.5,} \mathrm{5.1,} \mathrm{5.8).} \mathrm{This} \mathrm{study} \mathrm{provides} \mathrm{in-depth}$ knowledge regarding heat resistance of thermophilic bacteria in commercial products and expands our understanding regarding industrial sterilization process designing.

\section{References}

Ababouch, L. (2014). Heat treatment of foods: Spoilage problems associated with canning. Encyclopedia of Food Microbiology: 2nded., 2, 175-180. https://doi.org/10.1016/B978-0-12-384730-0.00157-9

Ahn, J., Balasubramaniam, V. M., \& Yousef, A. E. (2007). Inactivation kinetics of selected aerobic and anaerobic bacterial spores by pressure-assisted thermal processing. International Journal of Food

Microbiology, 113, 321-329. https://doi.org/10.1016/j.ijfoodmicro.2006.08.012

André, S., Zuber, F., \& Remize, F. (2013). Thermophilic spore-forming bacteria isolated from spoiled canned food and their heat resistance. Results of a French tenyear survey. International Journal of Food Microbiology, 165, 134-143.

https://doi.org/10.1016/j.ijfoodmicro.2013.04.019

André, S., Charton, A., Pons, A., Vannier, C., \& Couvert, O. (2021). Viability of bacterial spores surviving heat- 
treatment is lost by further incubation at temperature and $\mathrm{pH}$ not suitable for growth. Food Microbiology, 95, 103690. https://doi.org/10.1016/j.fm.2020.103690

André, S., Vallaeys, T., \& Planchon, S. (2017). Spore-forming bacteria responsible for food spoilage. Research in Microbiology, 168, 379-387.

https://doi.org/10.1016/j.resmic.2016.10.003

Bratt, L. (2013). Technical guide to fish canning. FAO GLOBEFISH Research Programme, 111, 1-69.

Bigelow, W. D., Bohart, G. S., Richardson, A. C., \& Ball, C. O. (1920). Heat penetration in processing canned foods. Bulletin No. 16L. National Canners Association.

Byrer, D. E., Rainey, F. A., \& Wiegel, J. (2000). Novel strains of Moorella thermoacetica form unusually heatresistant spores. Archives of Microbiology, 174, 334-339. https://doi.org/10.1007/s002030000211

Cameron, M. S., Leonard, S. J., \& Barrett, E. L. (1980). Effect of moderately acidic $\mathrm{pH}$ on heat resistance of Clostridium sporogenes spores in phosphate buffer and in buffered pea puree. Applied and Environmental Microbiology, 39, 943-949.

https://doi.org/10.1128/AEM.39.5.943-949.1980

da Silva, N., Taniwaki, M. H., Junqueira, V. C. A., Silveira, N., Okazaki, M. M., \& Gomes, R. A. R. (2018). Microbiological Examination Methods of Food and Water: A Laboratory Manual: 2nded. CRC Press LLC.

Delves-Broughton, J. (2008). Use of the natural food preservatives, nisin and natamycin, to reduce detrimental thermal impact on product quality. In-Pack Processed Foods: Improving Quality. Woodhead Publishing Limited. https://doi.org/10.1533/9781845694692.4.319

Durand, L., Planchon, S., Guinebretiere, M. H., Carlin, F., \& Remize, F. (2015). Geno- typic and phenotypic characterization of foodborne Geobacillus stearothermophilus. Food Microbiology, 45, 103-110. doi:10.1016/j.fm.2014.01.015

FDA (2020). Code of federal regulations Title 21, 114, 3. Retrieved from

https://www.accessdata.fda.gov/scripts/cdrh/cfdocs/cf cfr/CFRSearch.cfm?fr=114.3

Janštová, B., \& Lukášová, J. (2001). Heat resistance of Bacillus spp. spores isolated from cow's milk and farm environment. Acta Veterinaria Brno, 70, 179-184. https://doi.org/10.2754/avb200170020179

Jay, M. J., Loessner, J. M., \& Golden, D. A. (2005). Modern Food Microbiology: 7thed. Springer. doi:10.1007/b100840

Kirse-Ozolina, A., Muizniece-Brasava, S., Raits, E., Kruma, Z. (2019). Effect of sterilization parameters on the quality of commercially-prepared instant soups. Engineering for rural development, 22.-24.05.2019. (695-704). Latvia, Jelgava: Latvia University of Life Sciences and Technologies.
Kotzekidou, P. (2014). Bacillus: Geobacillus stearothermophilus (formerly Bacillus stearothermophilus). Encyclopedia of Food Microbiology: 2nded. Elsevier. https://doi.org/10.1016/B978-0-12-384730-0.00020-3

López, M., González, I., Mazas, M., González, J., Martin, R., \& Bernardo, A. (1997). Influence of recovery conditions on apparent heat resistance of Bacillus stearothermophilus spores. International Journal of Food Science and Technology, 32, 305-311. https://doi.org/10.1046/j.1365-2621.1997.00115.x

Mtimet, N., Guégan, S., Durand, L., Mathot, A. G., Venaille, L., Leguérinel, I., ... Couvert, O. (2016). Effect of pH on Thermoanaerobacterium thermosaccharolyticum DSM 571 growth, spore heat resistance and recovery. Food Microbiology, 55, 64-72. https://doi.org/10.1016/j.fm.2015.11.015

Mtimet, N., Trunet, C., Mathot, A. G., Venaille, L., Leguérinel, I., Coroller, L., \& Couvert, O. (2015). Modeling the behavior of Geobacillus stearothermophilus ATCC 12980 throughout its life cycle as vegetative cells or spores using growth boundaries. Food Microbiology, 48, 153-162. https://doi.org/10.1016/j.fm.2014.10.013

Palop, A., Raso, J., Pagán, R., Condón, S., \& Sala, F. J. (1999). Influence of $\mathrm{pH}$ on heat resistance of spores of Bacillus coagulans in buffer and homogenized foods. International Journal of Food Microbiology, 46, 243-249. https://doi.org/10.1016/S01681605(98)00199-8

Peng, J., Mah, J. H., Somavat, R., Mohamed, H., Sastry, S., \& Tang, J. (2012). Thermal inactivation kinetics of Bacillus coagulans spores in tomato juice. Journal of Food Protection, 75, 1236-1242. https://doi.org/10.4315/0362-028X.JFP-11-490

Rigaux, C., Denis, J. B., Albert, I., \& Carlin, F. (2013). A meta-analysis accounting for sources of variability to estimate heat resistance reference parameters of bacteria using hierarchical Bayesian modeling: Estimation of D at $121.1^{\circ} \mathrm{C}$ and $\mathrm{pH} 7$, zT and $\mathrm{zpH}$ of Geobacillus stearothermophilus. International Journal of Food Microbiology, 161, 112-120. https://doi.org/10.1016/j.ijfoodmicro.2012.12.001

Somavat, R., Mohamed, H. M. H., Chung, Y. K., Yousef, A. E., \& Sastry, S. K. (2012). Accelerated inactivation of Geobacillus stearothermophilus spores by ohmic heating. Journal of Food Engineering, 108, 69-76. https://doi.org/10.1016/j.jfoodeng.2011.07.028

Teixeira, A. (2006). Simulating Thermal Food Processes Using Deterministic Models. In: Thermal Food Processing, New Technologies and Quality Issues. CRC Press LLC.

Warne, D. (1988). Manual on Fish Canning. Rome: FAO

\section{Acknowledgments}

The authors thank the Institute of Food Safety, Animal Health, and Environment ("BIOR") for the opportunity to perform microbiological assays at the food microbiology laboratory.

The present research leading to these results in accordance with contract No. 1.2.1.1/18/A/002 between Latvian Food Competence Centre Ltd. and the Central Finance and Contracting Agency (08.05.2019) was conducted by Kronis Ltd. with the support of the European Regional Development Fund (ERDF) within the framework of the Latvian Food Industry Competence Center. 